\title{
RESEARCH
}

\section{PROTECTING OLDER WORKERS' HEALTH IN LEGAL TERMS COMPARATIVELY EUROPEAN ACQUIS IN THE LIGHT OF ILO R162}

Turkish Journal of Geriatrics

DOI: $10.31086 /$ tigeri.2020.176

2020; 23(3): 393-400

- Zeynep ŞişLi ${ }^{\text {(D) }}$

CORRESPONDANCE

Zeynep ŞişLi

Izmir University of Economics, Faculty of Law, izmir, Turkey

Phone: +902324889863

e-mail: zeynep.sisli@ieu.edu.tr

Received: Jun 12, 2020

Accepted: Jul 22, 2020

1 Izmir University of Economics, Faculty of Law, Izmir, Turkey

\section{Abstract}

Introduction: This article discusses the specific laws, regulations, and recommendations aimed at protecting older workers against occupational accidents and illnesses and whether they are properly regulated by Turkish legislation compared with the European Union acquis, in order to protect older workers against discrimination, and to make their working conditions more appropriate for their ages, in the light of International Labour Organization Recommendation No. 162.

Materials and methods: This conceptual article was prepared by evaluating the legal framework for protection of the occupational health and safety of older Turkish workers, through a comparison of Turkish law, International Labour Organization Recommendation No. 162, and the European Union acquis, and consideration of the facts reported in the relevant literature, using the document analysis method.

Results and Conclusion: Neither Turkish labour law nor European Union acquis include sufficient regulation to protect the health and safety of older workers at work. Older workers' health should be protected specifically by social law, without driving them to poverty. Changes in the regulation of working conditions that would be supported by the social security system have been proposed to protect the health of older workers as a specially protected group.

Keywords: Aging; Ageism; Legislation; Occupational health; Work 


\section{INTRODUCTION}

The number of older workers is increasing all over the world as a result of population aging. This situation is due to increasing life expectancy at birth. Birth rates, however, are decreasing, especially in developed countries (1). More older workers are required to work because legal retirement ages are rising and earlier access to pensions was limited in many countries after the 1990s when social security deficits become a menace to the sustainability of pensions within social insurance systems $(2,3)$. Therefore, many older workers continue to work because they cannot retire. In addition, old-age pensions and benefits are not sufficient for living in general. As a result, participation in the employment market is increasing among members of this population.

According to the European Agency for Safety and Health at Work (EU-OSHA), the employment rate of people aged 55-64 years in European Union (EU) countries increased from $39.9 \%$ in 2003 to $50.1 \%$ in 2013. However, according to the European Commission, the employment rate of this age group is not sufficient for sustainable growth of the European social market, citing the rate to be $46 \%$, compared with $62 \%$ in the United States and Japan. The European Commission's EUROPE 2020 Strategy Communication of 2010 (4) targeted the employment rates of older workers to secure the future of welfare systems. As a result, the employment rate of people aged 55-64 years increased to $58.7 \%$ in the EU in 2018 (5). The employment rate of these workers was 33.2\% in Turkey in 2019 according to Organisation for Economic Co-operation and Development (OECD) data (6). However, it was estimated to be much higher when shadow (informal) employment was included (33.42\%) in the official numbers for 2018 (7). There is a need for social protection programs that prevent poverty among elderly adults as a disadvantaged social group (8), and the low participation rate of people aged 55-64 years in the workforce is supposed to be a negative effect on the elderly poverty which would increase that need. That is why increasing participation rate of older workers to employment is in favour of the sustainability of social security systems not only related by pensions but as a whole.

On the other hand, because aging is associated with physical and psychological issues, older workers may encounter work-related problems that differ from those encountered by younger workers. These problems can be classified into two categories: age discrimination and being more vulnerable to occupational hazards and working conditions $(1,2)$. However older workers can be affected from work-related problems in different ways since there are some inequalities depending on the quality of the work they do and the social, economic and cultural conditions of the countries they live. Blue-collar workers are especially less educated and employed in jobs require more physical power compared to white-collar workers, and not wanted to be employed when they get older because of being under the higher risk of work accidents and occupational diseases and less productive due to the decreasing of the physical capacity by age. On the other hand, whitecollar workers are wanted in workplaces because of being more competent in time by gaining experience accompanied to their knowledge. But age becomes a disadvantage at last by affecting the mental and physical capacity negatively for all (9).

In the past decades, the International Labour Organization (ILO) General Conference has adopted certain proposals regarding older workers based on a specific recommendation from 1980. International Labour Organization Recommendation No. 162 (ILO R162) puts forward standards that promote equal opportunity for older workers and fair treatment of this population, for their protection and transition to retirement. It is stated in first article of ILO R162 that it will be applied 'to all workers who are liable to encounter difficulties in employment and occupation because of advancement in age', without declaring any specific age range because the experience of 
aging is not solely dependent on age. The World Health Organization Working Group on Aging and Working Capacity agreed that the terms 'older workers', 'aging workers' could be used to describe workers aged 45 years and above (10). However, older workers are generally described as being between 55 and 64 years of age in official documents and reports of European agencies.

This conceptual article discusses whether specific rules are regulated properly within Turkish legislation compared with the EU acquis to protect older workers against discrimination, and to make their working conditions more appropriate for their ages, in order to protect their health in the light of ILO R162. First, this article explains two types of problems older workers may encounter and how international law reflects these two types of problems. Then related provisions in Turkish law are explained with a discussion alongside the policies and reports prepared. Some proposals aimed at protecting the health of older workers have been put forward at last. These proposals focus on improvements in working conditions and fulfilling the legal obligations of the state and employers with regard to occupational health and safety; these proposals also emphasise the fact that the health of older workers should be protected specifically by social law without driving them to poverty, because the elderly are more vulnerable to fatal diseases, as has been demonstrated during the COVID-19 pandemic (11).

\section{MATERIALS AND METHODS}

A content analysis of the legislation, doctrine, and reports was conducted. The materials of the study are ILO R162 and reports of ILO as the universal legal approach to the subject, and the work for improving policies and legislation on European Union level and Turkish law in the sense of protection of health and safety of aging workers. Policy efforts for putting forward the legislation for protecting the health and safety of older workers in
Europe and the legal rules in Turkey are examined from two aspects as regulated by ILO R162 with the help of the research and reports about the subject below.

\section{EXAMINATION OF EUROPEAN ACQUIS AND TURKISH LAW IN THE LIGHT OF ILO R162}

International Labour Organization Recommendation No. 162 suggests that each member state should put forward social policies to promote equality of opportunity and treatment for all workers regardless of their age. This recommendation promotes the improvement of working conditions and the working environment at all stages of working life and supports the transition period to retirement through laws and practices, and the participation of the representative organizations of employers and workers. Measures should be taken to improve working conditions, such as adapting the job to the worker through technological and environmental changes, reducing normal daily and weekly hours of work for dangerous work, promoting the gradual reduction of work during a prescribed period until retirement, increasing the number of paid annual holidays on the basis of length of service or of age, enabling older workers to organize their work and leisure time (particularly by providing the opportunity for part-time employment and offering flexible working hours), facilitating the assignment of older workers to jobs performed during normal daytime working hours and not as shift work (1).

\section{Protection of Older Workers Against Discrimination}

Discrimination against individuals and groups is a serious problem that can be addressed through laws that protect human rights. Age discrimination can cause serious health problems (12), which is why employment discrimination should be considered an occupational health issue. Because the perspective of the study 
focuses on to adapt the working conditions in legal terms in order to protect health and safety of older workers, laws against age discrimination is taken into account as a tool to serve to this end. International and national laws protecting older workers from discrimination, as a disadvantaged group, emerged after the 1950s. The US Age Discrimination in Employment Act was enacted in 1967 'to protect applicants and employees 40 years of age and older from discrimination on the basis of age in hiring, promotion, discharge, compensation, or terms, conditions or privileges of employment' (13). Laws preventing age discrimination in employment have been enacted in Canada, Japan, New Zealand, and Austria (1). Age discrimination is considered an important issue by the United Nations (UN) and ILO because research has found evidence of its prevalence (14). The ILO Convention on Discrimination (Employment and Occupation) Convention, 1958 (No. 111) covered the subject, and ILO Older Workers Recommendation, No. 162, 1980 (ILO R162) is specific regulation against age discrimination (15). The UN adopted the International Plan of Action on Aging at the First World Assembly on Aging in Vienna in 1982, and the UN Principles for Older Persons in 1991, against age discrimination in general, which provided the foundation for the Madrid International Plan of Action on Aging 2002 (15). European Union Council Directive 2000/78/ EC aimed to ensure equal treatment of individuals regardless of their religion or beliefs, disability, age, or sexual orientation for equal access to employment and occupational opportunities, and membership to certain organizations, which included the protection of the elderly against discrimination (16).

Nevertheless, age equity in employment has moved closer to realization because of the abovementioned first efforts. According to an article in the Harvard Business Review, age was considered to be a competitive disadvantage by two-thirds of companies, which is consistent with other data showing that two-thirds of individuals aged 45 to 74 experienced age-related discrimination (17).

The EU has been criticized for having a conservative outlook on age-based distinctions, and an 'anti-ageist vision' has been suggested for its legal and policy framework to overcome injustice and prejudices based on age (18). The UN's World Population Aging 2019 report proposes that the elimination of age-related discrimination, including age barriers in employment, would increase productivity and promote economic growth. The report also points out that social policies that increase the participation of older persons in the formal market can contribute to the protection of rights and dignity (19). It is a fact that effective laws can protect older workers against discrimination by protecting their health at work.

\section{Providing Fair Working Conditions to Older Workers}

One Turkish study found that older workers have more physical health problems compared with younger workers, and, as demonstrated in similar studies conducted in different countries, working positively affects the health of older workers (20). Working conditions, such as long working hours without the amount of rest required for people in their age group, can lead to health problems even more for older workers than for other age groups. Working conditions should support the maintenance of health among older workers, especially against problems caused by postural and psychological stress, excess workload, hot and noisy environments, insufficient lighting, shift work, night work, and long working hours. It is recommended that the conditions that are harmful to the health of older workers first be itemized, then the priorities should be determined, and finally the items should be reorganized. Working conditions, equipment, and training should be specifically tailored according to the needs of older workers (9). Occupational accidents and diseases may be prevented through these procedures. The risk of catching occupational diseases cannot 
be significantly different because all employees work in the same workplace and are exposed to similar conditions; however, older workers can be more susceptible. In addition, older workers have chronic health problems, such as high blood tension and respiratory and circulatory system problems. As has been apparent during the COVID-19 pandemic, diseases caught at work can pose a greater health risk to older workers than to younger workers. Older workers may also place other workers at risk because they are unable to react and move easily and quickly. It is suggested that employers take appropriate precautions in the workplace in order to protect not only older workers but all workers. In addition, although the rate of occupational accidents encountered by older workers is lower than that of younger workers, because of having more experience and behaving more carefully, these accidents can be much more fatal for the former group (21).

Flexible work programs are the most common and offer the most effective method of maintaining motivation and productivity at work. They increase work satisfaction and productivity among older workers by decreasing work stress, absence, and fatigue. They also contribute to a better worklife balance. Another type of program that offers flexibility is gradual transition programs. These programs give older workers who only have a few years left before retiring the option to reduce their daily or weekly working hours. Through these programs, older workers can remain employed (utilizing their work experience) as they prepare for retirement (22).

Measures to Improve the Situation Older Workers were included in the agenda of the Council of Europe Steering Committee for Social Affairs for the adoption of the provisions of ILO R162 by member states, and a Draft Recommendation for Europe was formulated in 1980 (23). However, the only regulation enacted was a special provision for protection of the elderly in general (Article 23 of the European Social Charter [Revised] from
1996). Turkey has been a member state of the Council of Europe since 1950, and has adopted two main treaties on human rights: the European Convention on Human Rights and the European Social Charter, with some exceptions. The provision in the Revised European Social Charter is about providing a decent life to members of the general public, and does not specifically discuss older workers. There are specific provisions in the Charter for other worker groups that need special protection, such as employed women in maternity and child workers. There are no specific rules that protect older workers apart from those of the EU Occupational Safety and Health Framework Directive (89/391 EEC) and recommendations; however, research and policy discussions led by Eurofound and EU-OSHA, agencies of the EU, are ongoing.

\section{Legislation for Protection of Older Workers Against Discrimination and Providing Fair Working Conditions to Older Workers in Turkish Law}

According to Article 10 of the Turkish Constitution, everyone has equal protection under the law, but 'measures to be taken for women, children, the elderly, disabled people, widows and orphans of martyrs, invalids, and veterans shall not be considered a violation of the equality principle'. Article 49, on economic and social rights, states that 'Everyone has the right and duty of the work' and 'The State shall take the necessary measures to raise the standard of living of workers, and to protect workers and the unemployed in order to improve the general conditions of labour, to promote labour, to create suitable economic conditions for prevention of unemployment and to secure labour peace'. The first paragraph of Article 50, titled Working Conditions, Right to Rest and Leisure, which states, 'No one shall be required to perform work unsuited to his/her age, sex and capacity', could be said to specifically refer to older workers. However, the same Article goes on to state that 'minors, women, and physically 
and mentally disabled persons, shall enjoy special protection with regard to working conditions', before putting forward the general rule that 'all workers have right to rest and leisure'. Older workers are not specifically mentioned among the groups that required special consideration with regard to working conditions. Article 61 designates the elderly as one of the groups requiring special social protection in terms of social security but nothing is indicated about their rights at work. As a result, unsuitable work for one's age is banned in general, yet older workers are not mentioned within the groups to be protected, especially regarding working conditions. However, the fact that these measures offer protection to the elderly based on general principles of equality could serve as a legal basis for special laws to protect older workers' health. Discrimination based on age is forbidden by the Law on Turkish Human Rights and Equality Institution, but criticised by justifying the discrimination in employment under some particular conditions at the same time (24).

There are only two provisions concerning older workers in Turkish Labour Law. The first is Occupational Health and Safety Law No. 6331, which was enacted in 2012. The Law is based on EU 89/391 EEC. Article 10 (1)/d states that the situation of female workers and other workers such as young workers, older workers, disabled, pregnant or breastfeeding workers who need specific policies' should be considered as one of the points for assessment of the risks to health and safety of workers.

The second is regulated by Article 53 of Labour Law No. 4857 ('Right for Annual Paid Leave and Periods for Leave'). The amount of annual paid leave for workers ranges between 14 and 26 days, depending on seniority, according to this article, and cannot be less than 20 days for workers aged 18 years or less, and aged 50 years or more. Even though the amount of annual paid leave is regulated in favour of older workers, it is less than the minimum 4 weeks of annual leave stipulated in the Social Charter (Revised). Turkey was exempted when it ratified the Charter.

\section{RESULTS AND CONCLUSION}

According to a 2019 UN report, the aging population can positively affect economic growth while fiscal sustainability is maintained if appropriate social policies, based on the special conditions of each country, are implemented (19). Increasing the participation rate of older workers in the formal employment market is one method of achieving this aim. Nevertheless, the provision of healthy working conditions for older workers is necessary and is part of their basic rights. Measures that take into account the physical and mental changes that occur due to aging (23) should be implemented to improve working and environmental conditions among older workers. Neither European nor Turkish legislation sufficiently upholds the recommendations of ILO R162, even though European law contains better provisions and practices with regards to working conditions, not specifically for older workers, but all workers in general. Working conditions of older workers should be regulated by taking into account the specific needs of this population. Health and dignity could be protected at work through legislation and practice that reflect policy and research findings and focus on the 'right to life' as a basic human right. Flexible daily working hours and weekly working days can be provided without any loss of income with the support of the social insurance system, and annual paid leave periods can be increased. The impact of the work on health can be traced by occupational health surveillance. Measures should be taken to prevent discrimination due to age, which is partly caused by technological changes and intergenerational differences. The importance of protecting the health of older workers has been particularly apparent during the COVID-19 pandemic (11), which could be a topic for further research. States are obliged to develop regulations and build 
supporting organizations to monitor employer implementation of policies, with the help of social security systems. The health and safety of older workers and the protection of their right to life should be guaranteed, without driving them to poverty.

\section{ACKNOWLEDGEMENTS}

The author would like to thank Prof. Dr. Muzaffer Eskiocak for reviewing the paper and for his valuable comments.

\section{REFERENCES}

1. Ghosheh NS Jr, Lee S, McCann D. Conditions of Work and Employment for Older Workers in Industrialized Countries: Understanding the Issues. ILO Conditions of Work and Employment Series No. 15. [e-book] ILO Publication; 2006. [Internet]. Available from: https:// www.ilo.org/wcmsp5/groups/public/---ed_protect/--protrav/---travail/documents/publication/wcms_ travail_pub_15.pdf.

2. International Labour Organization (ILO). Social Protection for Older Persons: Policy Trends and Statistics 2017-2019. [e-book] ILO Publication; 2018. [Internet]. Available from: https://www.ilo.org/secsoc/ information-resources/publications-and-tools/policypapers/WCMS_645692/lang--en/index.htm.

3. Dubois $H$, Jungblut JM, Wilkens $M$, Wermeylen $M$, Vargas Llave O. EU-OSHA, Cedefop, Eurofound and EIGE Joint Report on Towards Age-Friendly Work in Europe: A Life-course Perspective on Work and Ageing from EU Agencies. [e-book] Publications Office of the European Union; 2017. (DOI:10.2802/130548).

4. European Commission. Communication from the Commission Europe 2020; A strategy for Smart, Sustainable and Inclusive Growth 2010. [Internet]. Available from: https:// eur-lex.europa.eu/legal-content/EN/TXT/ PDF/?uri=CELEX:52010DC2020\&from $=e n$.

5. European Union Statistical Office (EUROSTAT). Employment Statistics Data from May 2019. [Internet]. Available from: https://ec.europa.eu/eurostat/ statistics-explained/index.php/Employment_ statistics.

6. The Organization for Economic Co-operation and Development (OECD). Employment Rate by Age Group 55-64. [Internet]. Available from: https://data. oecd.org/emp/employment-rate-by-age-group. htm\#indicator-chart.

7. Social Security Institution (SGK). Informal Employment Rate based on Turkish Statistical institute Household Workforce Statistics. (in Turkish). [Internet]. Available from: http://www.sgk.gov.tr/wps/portal/sgk/tr/ calisan/kayitdisi_istihdam/kayitdisi_istihdam_ oranlari/kayitdisi_istihdam_orani.

8. İpek M. Global Impacts and Social Patterns in Shadow Employment. Labour and Society 2014;1:163186. (in Turkish). [Internet]. Available from: http:// calismatoplum.org/sayi40/ipek.pdf. Accessed: 1.5.2020.

9. Laville A, Volkoff S. Older Workers. (IIhan MN, Durukan, E. translated from Elderly Workers, Safety and Health at Work ILO CIS Bulletin 2001:4(15):217223). Turkish Journal of Occupational Health and Safety 2002;3 (10):41-47. (in Turkish). [Internet]. Available from: https://www.ttb.org.tr/dergi/index. php/msg/article/view/305/285.

10. World Health Organization (WHO). Aging and Working Capacity. [e-book\} WHO Technical Report Series 835; 1993. [Internet]. Available from: https:// apps.who.int/iris/bitstream/handle/10665/36979/ WHO_TRS_835.

11. Association of Public Health Specialist (HASUDER). Evaluation of 28 days of pandemic report. (in Turkish) [Internet]. Available from: https://korona.hasuder.org. tr/pandeminin-28-gun-degerlendirmesi/.

12. Jackson SE, Hackett RA, Steptoe, A. Associations between Age Discrimination and Health and Wellbeing: Cross-sectional and Prospective Analysis of the English Longitudinal Study of Ageing. The Lancet Public Health 2019; 4 (4). (DOI: https://doi. org/10.1016/S2468-2667(19)30035-0).

13. U.S. Department of Labor. Age Discrimination. [Internet]. Available from: https://www.dol.gov/ general/topic/discrimination/agedisc. 
14. Clark FLG. Physical Problems in the Employment of Aging Man. International Labour Review October 1957; 76: 367-382. Available from: https://heinonline. org/HOL/

15. Ghosheh N. Age Discrimination and Older Workers: Theory and Legislation in Comparative Context. Conditions of Work and Employment Series No. 20. [e-book] International Labour Organization; 2008. [Internet]. Available from: https://www.ilo.org/ wcmsp5/groups/public/---ed_protect/---protrav/--travail/documents/publication/wcms_travail_ pub_19.pdf.

16. European Agency for Safety and Health at Work. Directive 2000/78/EC-equal treatment. [Internet]. Available from: https://osha.europa.eu/en/ legislation/directives/council-directive-2000-78-ec.

17. Bersin J, Chamorro-Premuzik T. The Case for Hiring Old Workers. Harvard Business Review 2019. [Internet]. Available from: https://hbr.org/2019/09/ the-case-for-hiring-older-workers.

18. Georgantzi N. The European Union's Approach Towards Ageism. In: Ayalon L, Tesch-Römer C.(eds) Contemporary Perspectives on Ageism. International Perspectives on Aging (19) [e-book] Springer, Cham; 2018: 341-368. (DOI: 10.1007/978-3-319-73820-8_21).

19. UN Department of Economic and Social Affairs, Population Division 2019. World Population Aging 2019: Highlights. [e-book] Published by United
Nations; 2019. (ISBN: 978-92-1-004553-7).

20. Çağlayan Ç, Etiler N. Health of Older Workers in Turkey: A Further Analysis of a National Sample. Turkish Journal of Geriatrics 2015;18 (4): 285-292. [Internet]. Available from: http://geriatri.dergisi.org/ uploads/pdf/pdf_TJG_910.pdf.

21. Ofluoglu G, Özbucak Albar B. Ageing LabourOccupational Health and Safety Problems and Suggested Solutions. Hak İş Uluslararası Emek ve Toplum Dergisi 2017; 6 (15):335-360 (in Turkish). [Internet]. Available from: https://dergipark.org.tr/ en/pub/hakisderg/issue/30964/320550.

22. Özen S, Özbek Ç. Elderliness in Working Life: Old Workers and Human Resources Practices. Labour and Society 2017;2(53): 547-577. (in Turkish). [Internet]. Available from: http://www.calismatoplum.org/ sayi53/ozen-ozbek.pdf.

23. Ilmarinen JE. Aging Workers. Occupational and Environmental Medicine 2001;58 (8):546. (DOI: http:// dx.doi.org/10.1136/oem.58.8.546).

24. Sarıbay Öztürk, G. Old Age Discrimination Concerning the Termination of the Employment Contract, with Regard to the Law on Turkish Human Rights and Equality Institution. Sicil 2017;(37):114147. ISSN: 1306-6153. (In Turkish) [Internet] Available from: https://www.mess.org.tr/media/files/6751_ AFBNRLTR3Rsicil_37_.pdf. 